\title{
Fluorescent Glow
}

\section{MICOL HUTCHISON}

Virginia Commonwealth University, Richmond, VA, USA

\begin{abstract}
This narrative describes aspects of my semester teaching English as a Second Language in the city jail. I had expected to be able to draw grand conclusions about incarceration, inmates and policy, but instead I discovered that the inmates sitting in front of me were, above all else, simply students. The article also includes a digital story about the experience. The narrative is intended for those with interest in jail or prison education.
\end{abstract}

Keywords: English as a Second Language; jail education; prison education; incarceration.

There were days when my English as a Second Language class was easy to teach, when the students all seemed interested and engaged; and then there were the days when no one had any energy or questions, when the students were irritated with each other and with me. Sometimes I left the class with the sense that everyone had learned something; other times, I was pretty sure it had been a waste of an afternoon for all of us.

Even on those bad days, though, there were good moments. Manuel, for instance, always had a mental list of questions that started spilling out as he was still walking in the door. There was Saul, who was so quiet that I wasn't sure he understood anything, until one day he shyly asked me to read a poem he had written. He sat across the room from Eddie, who seemed unwilling to learn anything unless he could add it to his in-class stand-up comedy routine. There was also Franklin, who absorbed any information I gave him, and was the only student who wanted linguistic theory rather than basic conversational skills. And while there were some students who only came once or twice, I also had a large group of students who came to every class and always thanked me (referring to me as either "Teacher" or "Professor Micol") on their way out the door.

That was the semester that I began teaching a multilevel ESL class at the city jail. I've tried writing about this experience before, but the results always felt either self-aggrandizing or oversimplified. My attempts to articulate an overarching lesson or profound personal discovery failed each time. I think that may be because when I was offered the jail assignment, I had too little context and life experience to really understand the environment or its implications. In truth, I took the job primarily for its potential as either a good deed or an interesting adventure, and secondarily because every class I got helped pay off student loans.

The years since my jail assignment have brought a gradual understanding - an understanding of what I experienced, who my students were, and why my time in the jail was significant. I've also realized that these elements are much more important and meaningful than any grand lesson I could try to formulate.

I had only been teaching for a few years when I took this job, and until that time, I had found teaching to be exhilarating. Even when my teaching wasn't as smooth as I thought it should be, the classroom dynamic buoyed me, and I would end class feeling good. But at the jail, no matter how successful a lesson was, I was invariably exhausted at the end of the day. A fairly new teacher, I blamed myself for not being adequately prepared or for treating my students differently than I had previous groups. More realistically, it was the bright lights, the persistent low-level buzz, the watchful eyes, and the ubiquitous tension that left me mentally and physically tired.

Those who work full-time in jails and prisons must find ways to combat this powerful force. I'm not sure how those who live behind bars find the strength to fight lethargy and apathy, or to focus through the tension. As a young teacher, I wasn't thinking about anything outside of my Plexiglas-enclosed classroom. Now, I think of how the environment outside of school can affect learning; in education, we are concerned that students get a full night of sleep and a healthy breakfast - for an inmate, these might be the least of the situational detriments to learning.

My naivety highlights how little experience I had had with jails or prisons. This was long before all the CSIs made "forensic science" a household term, before $\mathrm{Or}$ ange is the New Black brought intrigue and indignation to Netflix-subscribers everywhere, and thus I didn't even have glamorized or gritty preconceived ideas of incarceration. When I first walked into the jail - in my early 20's, white and middle-class - my knowledge of the legal system was nearly non-existent. Though I knew people who had been in jail, it had always been brief, and either for youthful foolishness or respectable political protest. My students definitely did not fall into the latter category, and though they may have fit in the former category, their time in jail was rarely brief. 
In the years since, popular culture and louder voices for social justice have brought prison life a little closer, even for those who remain personally untouched. My life experience - even serving on jury duty - has triggered a greater awareness. Most impactful for me, I've met many students at my university who went through the legal system, and many more whose brothers, sisters, and parents have been incarcerated. I have seen how families split up, college plans disintegrate, and financial stresses mount. My ESL class likely had all of these misfortunes represented, and no doubt more: the majority of the students were undocumented immigrants.

When I tried to find the lesson in my jail teaching experience before, I was stymied by one big factor, the thing that took me the longest to understand: my sympathy had always been mitigated by the knowledge that most of my students were in jail because they had committed a crime. And I was comfortable with the fact that a crime brings with it punishment. As a consequence, I saw my students' time in this stressful environment as unpleasant but not entirely unfair.

What I didn't see then was the imbalance that privilege confers: how my brother's arrest for shoplifting resulted in nothing more than a humiliating call to my parents; how the charge of marijuana possession became a few hours of community service for my best friend; how my own teenage street sign theft was immature but amusing, the reprimand by the police initially anxiety-provoking but later just laughterinducing. Had we not been middle class, had we not been driving our parents' cars, had we not known how to articulate embarrassment and regret at the right time, we might have been hit with jail time and felony convictions rather than slapped on our predominantly white wrists.

I thought my students were different from me, and they were. But not so much because of the crimes they committed as because of their circumstances, the background that perhaps drove them to the crimes, but more likely translated those crimes into jail time. It's unlikely that I could have been the student in the jail class - not because I was more law-abiding than they, but because I was far luckier.

Since my time in the jail classroom, I have come to understand on a personal level how much of a role race and class can play in the legal system. I am aware of the school-to-prison pipeline and the prison-industrial complex. Being born lower-class or black does not relegate an individual to a life behind bars, nor does being Latino guarantee a lack of access to a decent education, but I know now how early and easily these paths can appear.

But when I was standing in front of my class at the city jail, I thought of none of this. Even as a politically aware young adult, I knew little of it.

In my earlier writing about my class at the jail, I had wanted to espouse public policy, issue ethical mandates, draw conclusions about political legislation. I knew there was significance in what I saw and felt at the jail. But in reality, I experienced a class - one that was really frustrating at times, and wonderfully satisfying at others. Some of the students were intensely motivated, while others were there because it was less boring than sitting in the common room. There were smart students and slower ones. It was a class with Manuel and Saul and Eddie and Franklin. In these ways, it was a class just like the ones I teach year after year at the university. It may have taken place under fluorescent lights and a watch tower, with inadequate desks and only a handful of pencils, but ultimately, it was a class of individuals, all of whom could learn, many of whom had had limited opportunities, and all of whom - I now say with confidence - deserved the chance.

My time in the jail did not qualify me to espouse, issue, or draw the conclusions I had thought I should, but it turned a group of 30 inmates into my students, and those students eventually, slowly, opened my eyes.

$$
* * *
$$

In addition to Manuel, Saul, Eddie, and Franklin, there was Carlos. Here is my story about him: Click on the link below.

\section{http://youtu.be/eBxmQIXfgRU}

Please note: All images used in this video are from the Creative Commons of Flickr.

Micol Hutchison is an instructor in the Department of Focused Inquiry at Virginia Commonwealth University, as well as a doctoral student in VCU's School of Education. Her research interests currently center on first-generation college students and their path through higher education. 